\title{
Nutrient and plankton development in Rosfjorden and enclosed ecosystems captured from changing water bodies during POSER
}

\author{
G. Kattner ${ }^{1}$, K. D. Hammer ${ }^{1}$, K. Eberlein ${ }^{1}$, U. H. Brockmannn ${ }^{1}$, J. Jahnke ${ }^{2}$ \\ and M. Krause ${ }^{3}$ \\ ${ }^{1}$ Institut für Organische Chemie und Biochemie, SFB 94, Universität Hamburg, Martin-Luther-King-Platz 6, \\ D-2000 Hamburg 13, Federal Republic of Germany \\ ${ }^{2}$ Institut für Biologie I (Botanik), Abteilung für Systematik und Geobotanik, RW Technische Hochschule Aachen, Melaten, \\ Worringerweg, D-5100 Aachen, Federal Republic of Germany \\ ${ }^{3}$ Sonderforschungsbereich 94 an der Universität Hamburg, Bundesstraße 55, D-2000 Hamburg 13, \\ Federal Republic of Germany
}

\begin{abstract}
During POSER (Plankton Observations with Simultaneous Enclosures in Rosfjorden) in spring 1979, nutrient and plankton development were investigated in an open south Norwegian fjord and in different enclosures. Enclosures were plastic tubes, $1 \mathrm{~m}$ in diameter and up to $40 \mathrm{~m}$ long, fastened to a central float. The water in the fjord exchanged several times. This could be well documented also by changes in nutrient, phyto- and zooplankton concentrations. Water with different plankton and nutrient concentrations was enclosed in order to exclude advective processes. The experiment was divided into 3 main periods. In the first period the water in the fjord was haline, nutrient-rich, and slightly stratified, due to a bloom of Skeletonema costatum. During this phase the phytoplankton disappeared in the fjord and in the enclosures within $6 \mathrm{~d}$, likely due to low light intensities. In the second period, following a water exchange, the water was less haline, poorer in nutrients, and richer in phytoplankton (mainly Thalassiosira nordenskioeldii) and in zooplankton. Part of this water was enclosed until silicate and phytoplankton concentrations became depleted and the major zooplankton species, Calanus finmarchicus, had developed to the third copepodite-stage. In the third period, following a new upwelling of haline and nutrient-rich water up to $10 \mathrm{~m}$ depth, 1 enclosure was filled with well-stratified water, nutrient-poor in the upper layer, but nutrient-rich below. In spite of sufficient nutrients the phytoplankton biomass decreased in this enclosure as well as in the fjord. This was partly caused by increasing numbers of copepodites, which reached more than $50 \%$ of the phytoplankton biomass during the last $8 \mathrm{~d}$ of our observations.
\end{abstract}

\section{INTRODUCTION}

Enclosure experiments facilitate investigations of marine ecosystems, as horizontal advections are excluded and patchy distributions reduced. While natural conditions are essentially maintained, some parameters are altered by enclosing plankton populations, e.g. turbulence; furthermore, plastic foils may affect plankton development.

We investigated interactions of the first trophic levels of the food web during spring and demonstrate and discuss here the interdependence of chemical and biological factors. Our studies were carried out in water enclosed in bags and in the ambient fjord water. During POSER (Brockmann et al., 1983) the biological and chemical changes in enclosures and fjord were monitored by measuring phytoplankton, zooplankton and nutrient concentrations.

The water in the fjord changed several times due to meteorological conditions (Brockmann et al., 1981). Thus, we could enclose water with different biological and chemical qualities. Correlations between phytoplankton development and primary production have been studied by Jahnke et al. (1983).

\section{METHODS}

Enclosures were fastened to a central float, anchored at a water depth of 60 to $80 \mathrm{~m}$ in the Børøy Bight of 


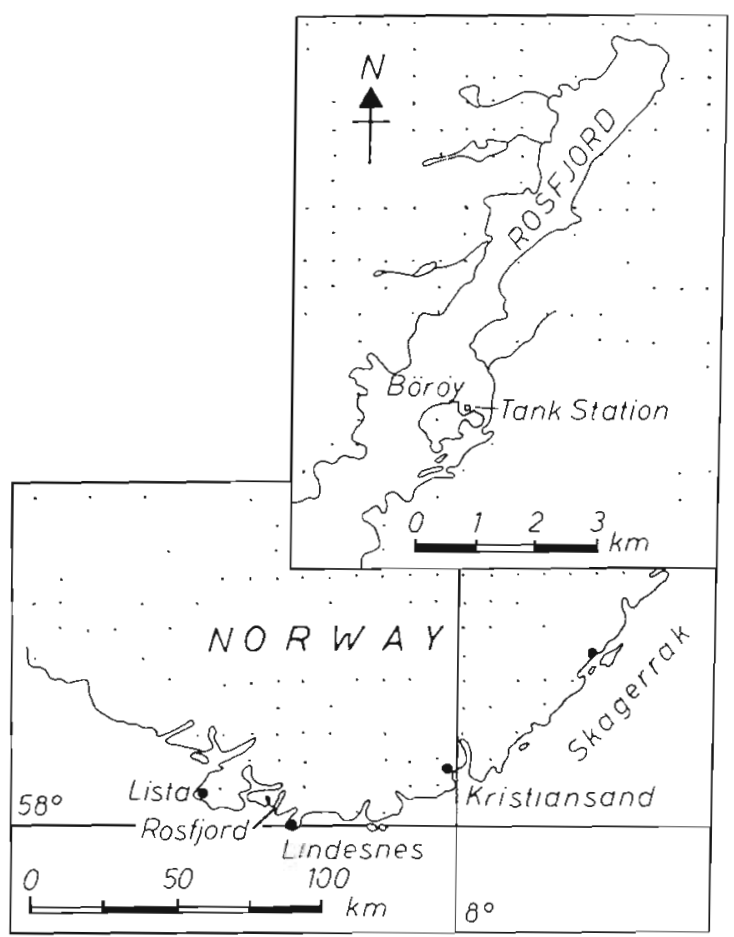

Fig. 1. Location and map of the POSER site in the Borøy Bight of Rosfjord, southern Norway

Rosfjorden, southern Norway (Fig. 1). All enclosures were flexible, seamless plastic tubes (Brockmann et al., 1974), about $40 \mathrm{~m}$ long and $1 \mathrm{~m}$ in diameter. Bags were prepared from rolled-up tubes by closing the bottom. The bottom was then weighted (about 10 to 20 $\mathrm{kg}$ ), to keep the bags in a vertical position. For filling, the collapsed tubes were drawn into the water by the weights. The bag was fastened to an aluminium collar kept in place by 3 lines. The bag was lowered until the collar reached a depth equivalent to the length of the bag. Raising the bag with a winch on the ring station allowed the bag to fill, thus maintaining the stratification of the water column in the fjord at the time of filling.

Samples of phytoplankton and for chemical analysis were collected by a $3 \mathrm{dm}^{3}$ sampler (Brockmann and Hentzschel, 1983) at standard depths of $0,3,10,20$ and $35 \mathrm{~m}$. All samples for chemical measurements $1500 \mathrm{ml}$ each) were filtered through glass-fibre filters (Whatman $G F / C, 1.2 \mu \mathrm{m}$ retention ability). Nitrate plus nitrite, ammonia, silicate, and phosphate were measured immediately near the station by a Technicon AutoAnalyzer (Eberlein et al., 1983). Chlorophyll was extracted with $90 \%$ acetone from frozen glass-fibre filter residues. Chlorophyll was calculated according to Lorenzen (1967). Samples for phytoplankton counting were fixed (formaldehyde method) at a final concentration of $2 \%$. Samples were counted directly applying inverse microscopy. Cells were measured and, by calculating their volume, phytoplankton biomass was estimated with conversion factors given by Hagmeier (pers. comm.) (see Table 1).

At each depth, 2 zooplankton samples were obtained by a $3 \mathrm{dm}^{3}$ sampler. The 2 samples were then combined in order to increase their representativeness. For counting zooplankton and larger phytoplankton cells, $5 \mathrm{dm}^{3}$ were filtered through gauze filters $(20 \mu \mathrm{m})$ and then fixed with formaldehyde. Zooplankton biomass was calculated from the numbers of organisms present (Krause and Kattner, 1983). Zooplankters of some representative samples were measured and the corresponding conversion factors (Hagmeier, pers. comm.; Smetacek, 1975; Williams and Lindley, 1980) used (tabulated by Krause and Kattner, 1983).

Table 1. Phytoplankton during POSER. Size and conversion factors (Hagmeier, pers. comm.) used to estimate phytoplankton biomass

\begin{tabular}{|c|c|c|c|}
\hline \multicolumn{2}{|c|}{ Phytoplankton } & \multirow{2}{*}{$\begin{array}{l}\text { Size } \\
(\mu \mathrm{m})\end{array}$} & \multirow{2}{*}{$\begin{array}{l}\text { ng C } \\
\text { cell }^{-1}\end{array}$} \\
\hline \multicolumn{2}{|l|}{ Diatoms } & & \\
\hline Centric & Skeletonema costatum & $5 \times 8$ & 0.02 \\
\hline \multirow[t]{5}{*}{ diatoms: } & Centric diatoms & 20 & 0.15 \\
\hline & & 30 & 0.50 \\
\hline & & 40 & 1.00 \\
\hline & & 60 & 3.00 \\
\hline & & 100 & 9.00 \\
\hline \multirow{15}{*}{$\begin{array}{l}\text { Pennate } \\
\text { diatoms: }\end{array}$} & Chaetoceros sp. & $8 \times 25$ & 0.15 \\
\hline & & $33 \times 7$ & 0.20 \\
\hline & C. borealis & $15 \times 30$ & 0.20 \\
\hline & C. debilis & $10 \times 10$ & 0.04 \\
\hline & C. diatoma & $12 \times 24$ & 0.15 \\
\hline & C. socialis & $10 \times 10$ & 0.04 \\
\hline & Rhizosolenia shrubsolei & $8 \times 420$ & 4.00 \\
\hline & R. hebetata & $8 \times 420$ & 4.00 \\
\hline & $R$. alata & $8 \times 420$ & 4.00 \\
\hline & Nitzschia seriata & $80 \times 12$ & 0.80 \\
\hline & N. longissima & $5 \times 130$ & 0.10 \\
\hline & $\begin{array}{l}\text { Thalassiosira norden- } \\
\text { skioeldij }\end{array}$ & $12 \times 20$ & 0.20 \\
\hline & T. polychorda & $35 \times 60$ & 1.00 \\
\hline & $\begin{array}{l}\text { Thalassionema nitz- } \\
\text { schioides }\end{array}$ & $8 \times 40$ & 0.20 \\
\hline & Pennate diatoms & $84 \times 14$ & 0.80 \\
\hline \multicolumn{4}{|c|}{ Peridineans } \\
\hline \multirow[t]{4}{*}{ Dinophyc } & : Gyrodinium sp. & 50 & 0.50 \\
\hline & & 150 & 12.00 \\
\hline & Non-thecate flagellates & $8 \times 15$ & 0.05 \\
\hline & Thecate flagellates & $30 \times 50$ & 2.00 \\
\hline \multirow[t]{7}{*}{ Ciliates } & & $35 \times 50$ & 2.00 \\
\hline & & $28 \times 35$ & 2.00 \\
\hline & & 50 & 6.00 \\
\hline & & $30-40$ & 2.00 \\
\hline & & 32 & 2.00 \\
\hline & & $20-28$ & 0.80 \\
\hline & & 20 & 0.50 \\
\hline
\end{tabular}


At the beginning of the experiment, 2 enclosures (Bags $U$ and $V$ ) with a length of $40 \mathrm{~m}$ and 1 enclosure with a length of $10 \mathrm{~m}$ were filled with nutrient-rich and plankton-poor water. Following exchange of the fjord water, another enclosure (Bag BB) was filled with Skagerrak water reaching the station on March 12/13. The last enclosure (Bag CC) was filled after a further water exchange with nutrient-poor water in its upper part and nutrient-rich water below.

\section{RESULTS}

The measurements in the fjord started on March 2. The water in the fjord exchanged several times (Brockmann et al., 1981). Fig. 2a illustrates changes in nitrate + nitrite, silicate and phosphate in the fjord; Fig. $2 b$ shows chlorophyll and phytoplankton biomass data. For the last period, the increase in large-sized phytoplankton is illustrated in Fig. $2 b$ by a third curve
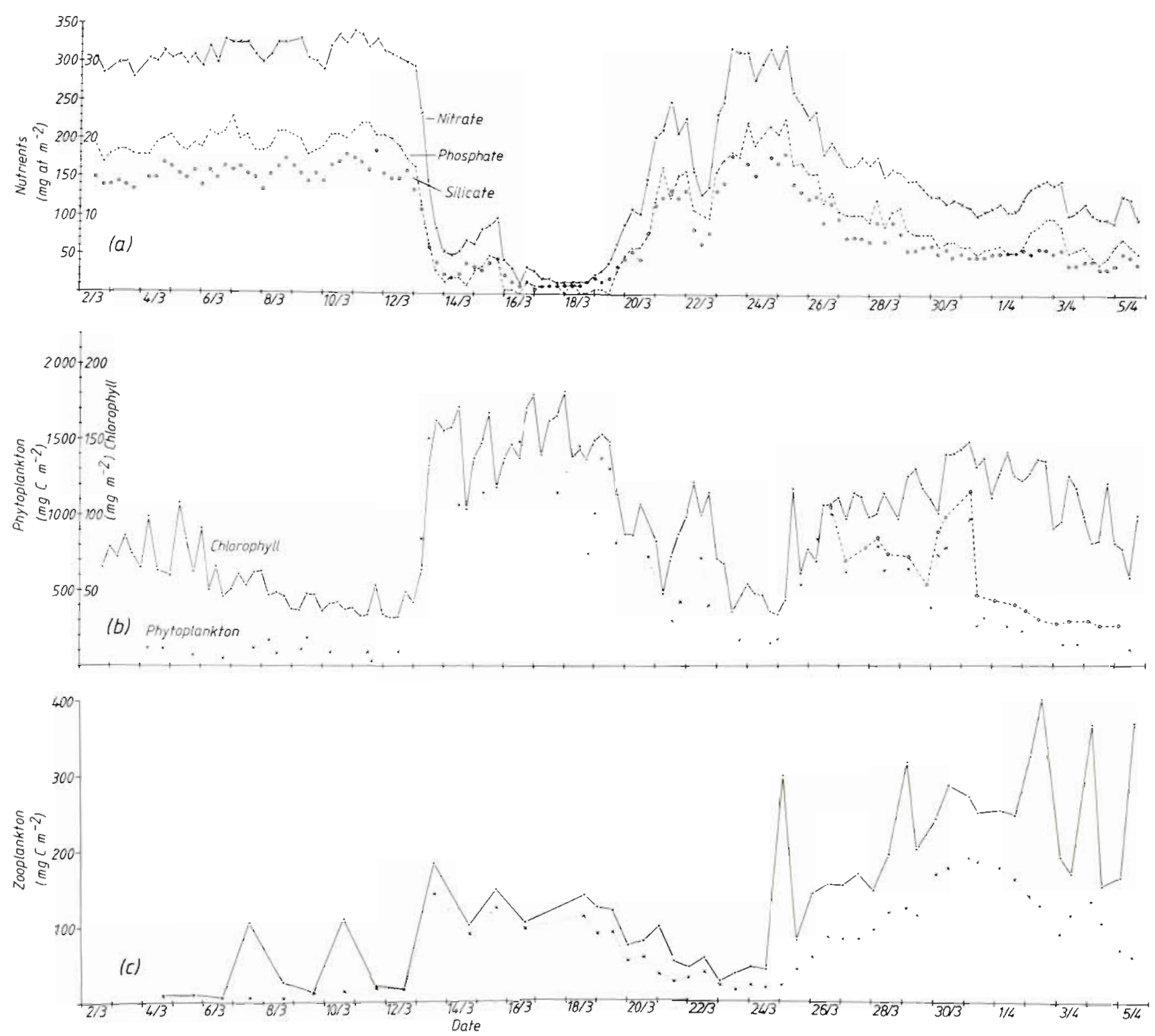

Fig. 2. Biological and chemical development in Rosfjord. Values calculated under $1 \mathrm{~m}^{2}$ of surface area to a depth of $40 \mathrm{~m}$. (a) Concentration of nutrients: $x$ nitrate; • phosphate; o silicate. (b) Concentration of chlorophyll (•); phytoplankton biomass $\times$; phytoplankton biomass including large phytoplankters (ㅇ). (c) Total zooplankton biomass (•); biomass without copepods and copepodite-stages $(x)$ 


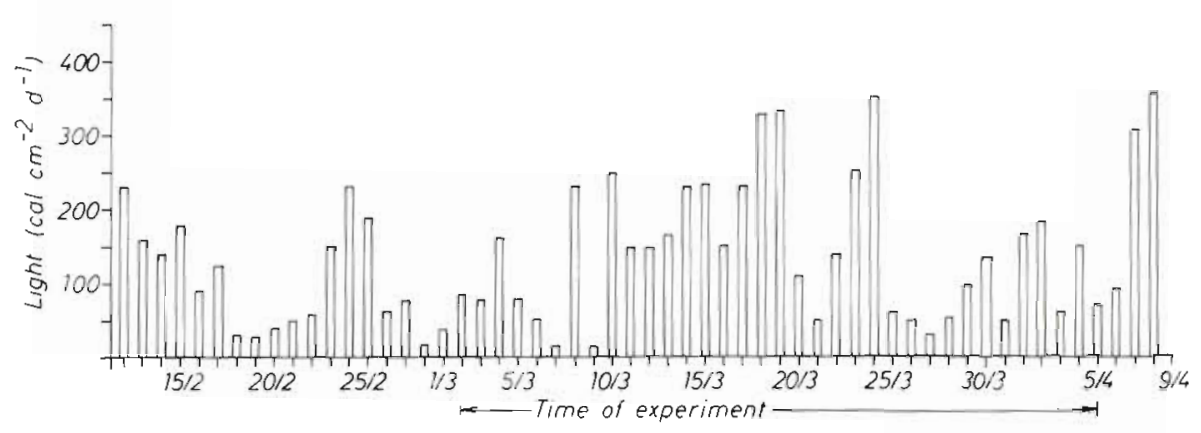

Fig. 3. Integrated daily incident light at Kjevik airport (which kindly provided the data)

showing the sum of both, smaller and larger phytoplankters. Fig. 2c shows the total zooplankton biomass and the zooplankton biomass without the different copepodite-stages and adults.

Integrated incident light measurements were taken from records at Kjevik airport in southern Norway (Fig. 3), because light measurements at the central float first started on March 7. Both measurements are linearly correlated ( $99 \%$ confidence). For other physical measurements, especially temperature and salinity, consult Brockmann et al. (1981).

In Fig. 4 the nutrient distribution, exemplified by phosphate, is shown for the fjord together with the development in the different enclosures. On account of the different water masses associated with our enclosure experiments the observations are divided into 3 main periods.

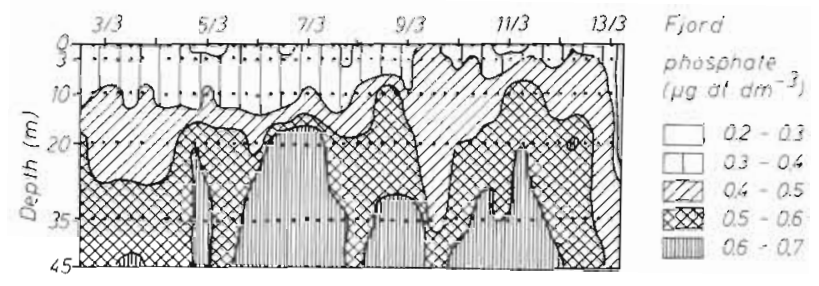

Fig. 5. Distribution of phosphate concentration in the fjord during first period

increased with depth from 0.3 to 0.4 in the upper part, to 0.6 to $0.7 \mu \mathrm{g}$ at $\mathrm{P} \mathrm{dm} \mathrm{dm}^{-3}$ at about $20 \mathrm{~m}$. Maximum values of nutrients were recorded at $20 \mathrm{~m}$ : nitrate, 9 to $10 \mu \mathrm{g}$ at $\mathrm{N} \mathrm{dm}^{-3}$; phosphate, 0.6 to $0.7 \mu \mathrm{g}$ at $\mathrm{P} \mathrm{dm}{ }^{-3}$; silicate, 5 to $6 \mu \mathrm{g}$ at $\mathrm{Si} \mathrm{dm}^{-3}$.

Stratification of nutrients is evidence for phytoplankton growth prior to starting the experiment. The

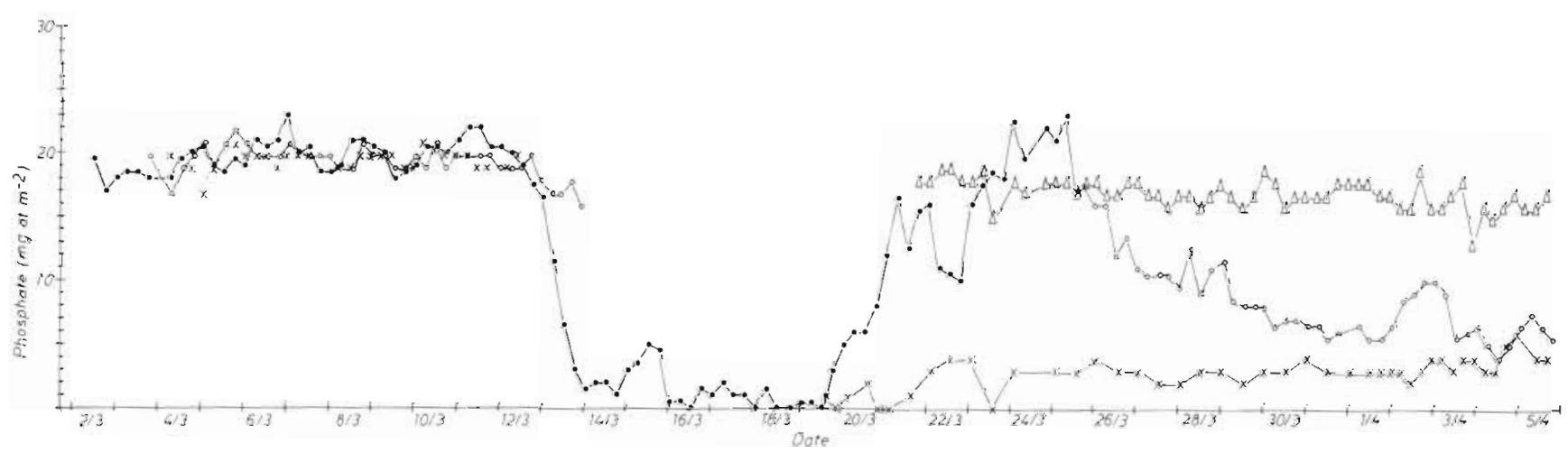

Fig. 4. Development of phosphate concentrations (calculated as in Fig. 1) in fjord and in enclosures. •fjord; $\circ$ Bag $U_{;} \times \ldots \times B_{a g} V_{i}$ $\times-\times \mathrm{Bag} B B_{i} \triangle \mathrm{Bag} \mathrm{CC}$

\section{Period 1: March 3 to 12}

Fjord

At the beginning of the experiment the salinity of the nutrient-rich water ranged from 33 to 34 , the temperature from 5 to $6{ }^{\circ} \mathrm{C}$ (Brockmann et al., 1981). Physical and biological stratification of the water column was already present. An example of the stratification is the phosphate distribution (Fig. 5). Phosphate values dominating phytoplankter was Skeletonema costatum; it appeared in concentrations of up to 300,000 cells $\mathrm{dm}^{-3}$; however, due to its small cell size, its contribution to the total biomass was low. In some samples of one profile (March 5) more than 3 million cells $\mathrm{dm}^{-3}$ of S. costatum were found. Some days later (March 8) S. costatum totally disappeared. Chatoceros debilis was another main species in this period. Also Thalassiosira nordenskioeldii was already present with maximum cell concentrations of 10,000 cells $\mathrm{dm}^{-3}$ at some 


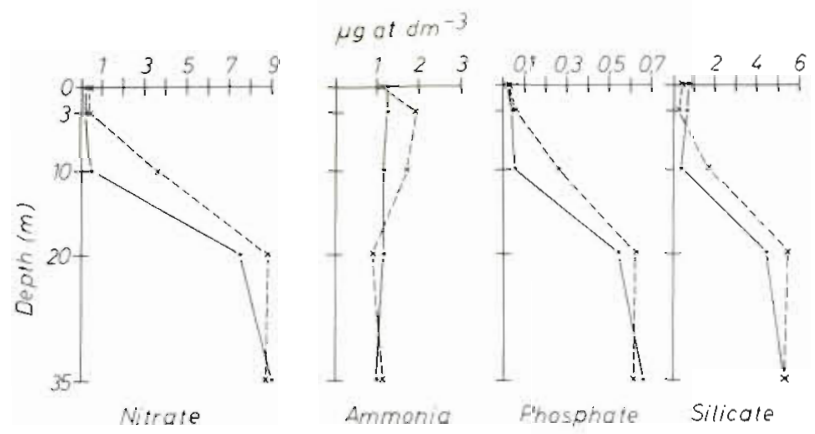

Fig. 6. Profiles of nutrient concentrations during filling of Bag U at $19.00 \mathrm{~h}$ on March 3. - fjord; $x$ enclosed in Bag U

\section{Bag U}

On March 3, Bag U was filled with nutrient-rich water. It was possible to preserve the stratification of nutrients in the fjord inside the enclosure (Fig. 6). A slight displacement of concentrations occurred only at a depth of $20 \mathrm{~m}$. The stratification could also be maintained during the course of this experiment, until March 14, when the enclosure was destroyed by strong currents causing exchange of water in the fjord.

During the first experiment, the nutrient concentrations generally remained constant in the enclosure as

Fig. 7. Silicate concentrations in

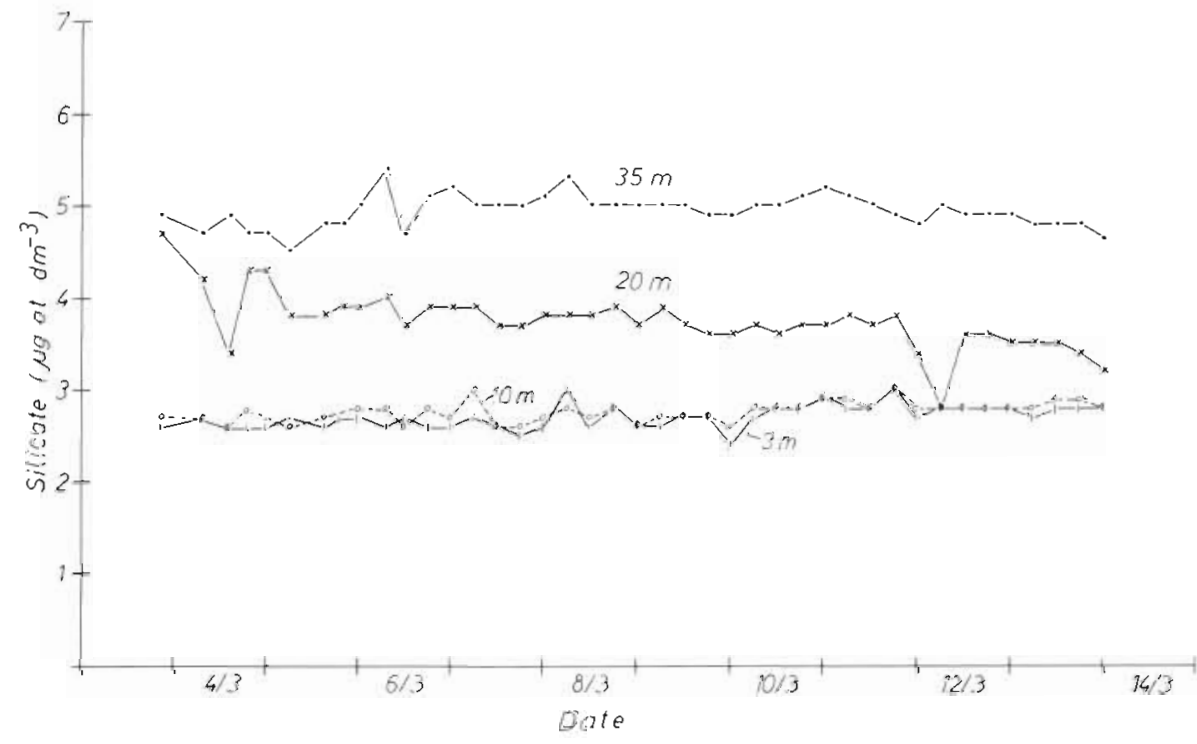

depths on March 8 and 9, but it decreased to a few thousand cells $\mathrm{dm}^{-3}$ on March 10 .

Zooplankton biomass was low during this period reaching only about $5 \%$ of the phytoplankton biomass. The 2 higher values on March 7 and 10 were not representative; they resulted from single adults, winter-surviving females of Calanus finmarchicus in the water column. A slight biomass increase towards the end of this period was due to increases in nauplii numbers.

Fig. 8. Skeletonema costatum. Development during first period (values averaged to a depth of $40 \mathrm{~m}$ ). $\bullet$ fjord; $\times$ Bag U; O Bag V

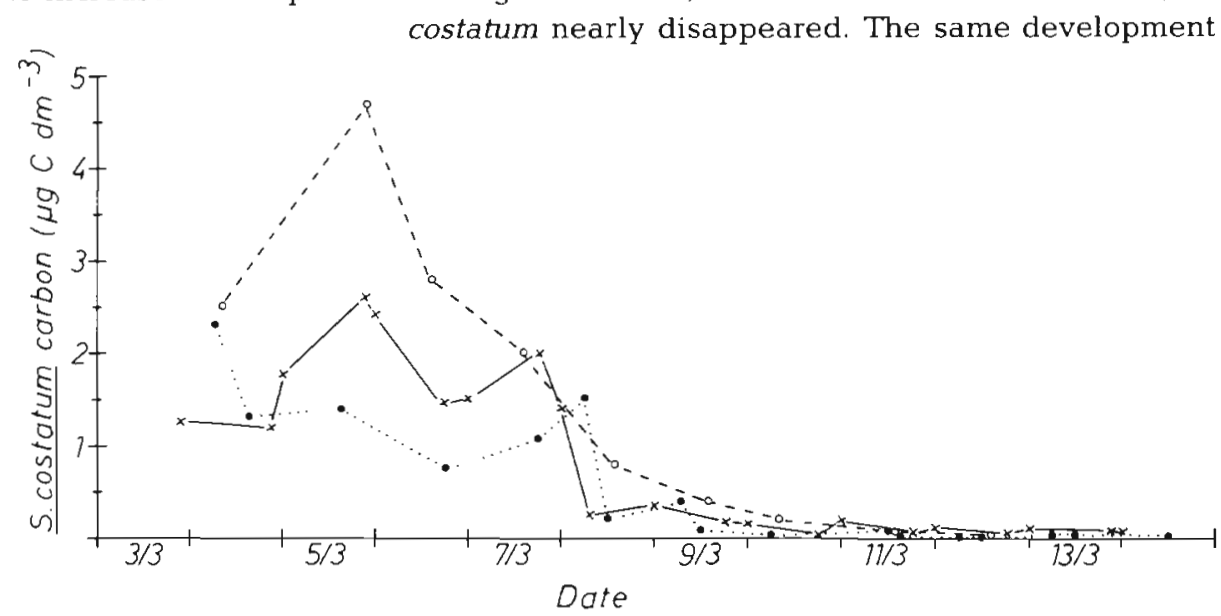


Table 2. Average nutrient concentrations during the first period of the experiment

\begin{tabular}{|llll|}
\hline & Nitrate & $\begin{array}{c}\text { Silicate } \\
\left(\mu g \text { at } \mathrm{dm}_{1}{ }^{-3}\right)\end{array}$ & Phosphate \\
\hline Fjord & $7.97 \pm 5.3 \%$ & $4.00 \pm 7.0 \%$ & $0.50 \pm 6.0 \%$ \\
Bag U & $7.87 \pm 3.3 \%$ & $3.76 \pm 4.0 \%$ & $0.49 \pm 4.1 \%$ \\
Bag V & $7.90 \pm 3.3 \%$ & $3.79 \pm 3.4 \%$ & $0.49 \pm 4.1 \%$ \\
\hline
\end{tabular}

could be observed in the fjord (Fig. 8). The other main phytoplankton species, Chaetoceros debilis, featured more than 30,000 cells $\mathrm{dm}^{-3}$ in Bag $\mathrm{U}$ and in the fjord. C. debilis showed no development and disappeared along with the phytoplankton on March 8 . Only on March 14 was there again a slight increase in the abundance of main species. The zooplankton biomass in this enclosure was as low as in the fjord, but around March 9 it increased slightly due to the appearance of some copepodite-stages (Fig. 9).

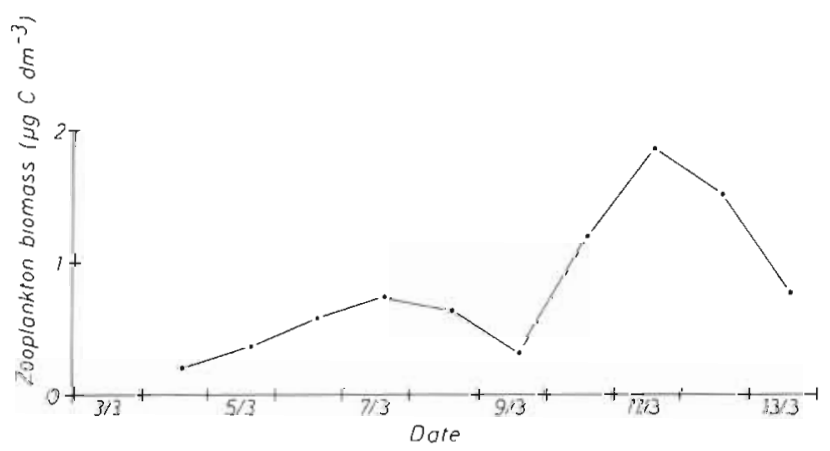

Fig. 9. Development of zooplankton biomass in Bag U during first period (values averaged to a depth of $40 \mathrm{~m}$ )

\section{Bag V}

Bag $\mathrm{V}$ was filled $1 \mathrm{~d}$ later than Bag $\mathrm{U}$ in order to demonstrate the parallel development in both enclosures. This enclosure was also destroyed like Bag U on March 14. The mean concentrations of nutrients were identical with the concentrations in Bag U (Table 2). Skeletonema costatum developed in general as in Bag U (Fig. 8), but its maximum concentrations were higher, since the cell numbers at the time of bag filling were higher in the fjord. During the first days, cell doubling time was about 30 to $40 \mathrm{~h}$ in both enclosures.

\section{Period 2: March 13 to 19}

\section{Fjord}

Water exchange in the fjord started at noon, March 12 ; the water totally changed within $24 \mathrm{~h}$. Down to a depth of $50 \mathrm{~m}$ the nutrient-rich water was replaced by nutrient-poor Skagerrak water (Fig. 2a) with mean concentrations of $1.10 \pm 0.64 \mu \mathrm{g}$ at $\mathrm{N} \mathrm{dm}^{-3}$ for nitrate; $0.60 \pm 0.29 \mu \mathrm{g}$ at $\mathrm{Si} \mathrm{dm}^{-3}$ for silicate; and $0.04 \pm 0.04$ $\mu \mathrm{g}$ at $\mathrm{P} \mathrm{dm}^{-3}$ for phosphate. Especially the phosphate supply was nearly exhausted. Chlorophyll and phytoplankton carbon reached maximum concentrations (Fig. 2b). The distribution of phytoplankton was relatively homogeneous in the upper $40 \mathrm{~m}$ (Jahnke et al., 1983).

The bulk of phytoplankton consisted of Thalassiosira nordenskioeldii with nearly half of the total biomass. At the beginning (March 13), T. nordenskioeldii attained mean values of 200,000 cells $\mathrm{dm}^{-3}$ (maximum 450,000 cells $\mathrm{dm}^{-3}$ ). Other main species were Thalassionema nitzschioides and Chaetoceros debilis. During this period, the phytoplankton share in the total biomass decreased slightly. Large fluctuations were caused by the patchy distribution of dinoflagellates. On March 15/16, a short-time upwelling of nutrientrich water with low plankton concentrations occurred up to $40 \mathrm{~m}$ depth.

During the second period the water body was characterized also by the zooplankton biomass (Fig. 2c); it had increased parallel to the phytoplankton biomass. This was due to an increase in the nauplii population, attaining more than $10 \mathrm{ind} . \mathrm{dm}^{-3}$. Little changes occurred in the copepodite stages and in the adults. The ratio of zooplankton carbon to phytoplankton carbon of about 1 to 20 did not change compared to the first period.

\section{Bag BB}

Bag BB was filled with nutrient-poor Skagerrak water on March 19, a short time before the new upwelling started. In accordance with the mean concentrations in the fjord (Fig. 10) the initial concentrations of nutrients, averaged over all depths, were for nitrate, $1.35 \mu \mathrm{g}$ at $\mathrm{N} \mathrm{dm}^{-3}$; for silicate, $0.69 \mu \mathrm{g}$ at $\mathrm{Si} \mathrm{dm}{ }^{-3}$; and for phosphate, $0.02 \mu \mathrm{g}$ at $\mathrm{P} \mathrm{dm}^{-3}$. Dominated by Thalassiosira nordenskioeldii, the phytoplankton dis-
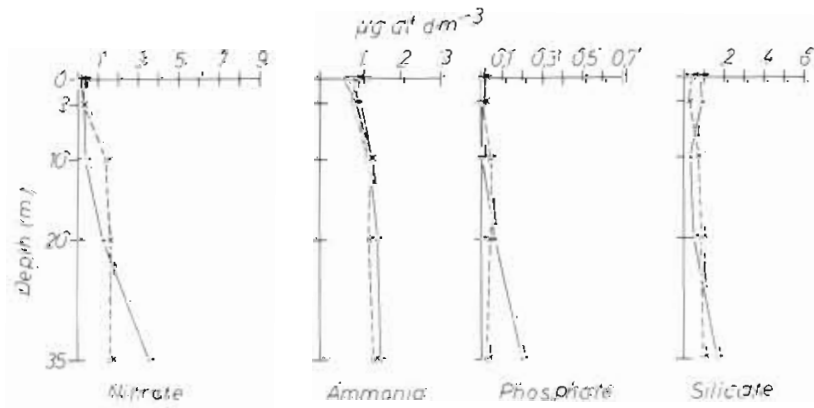

Fig. 10. Profiles of nutrient concentrations during filling of Bag BB at 17.00 h on March 19. $\bullet$ fjord; $\times$ enclosed in Bag BB 
Fig. 11. Concentrations of phytoplankton biomass in Bag BB at different depths

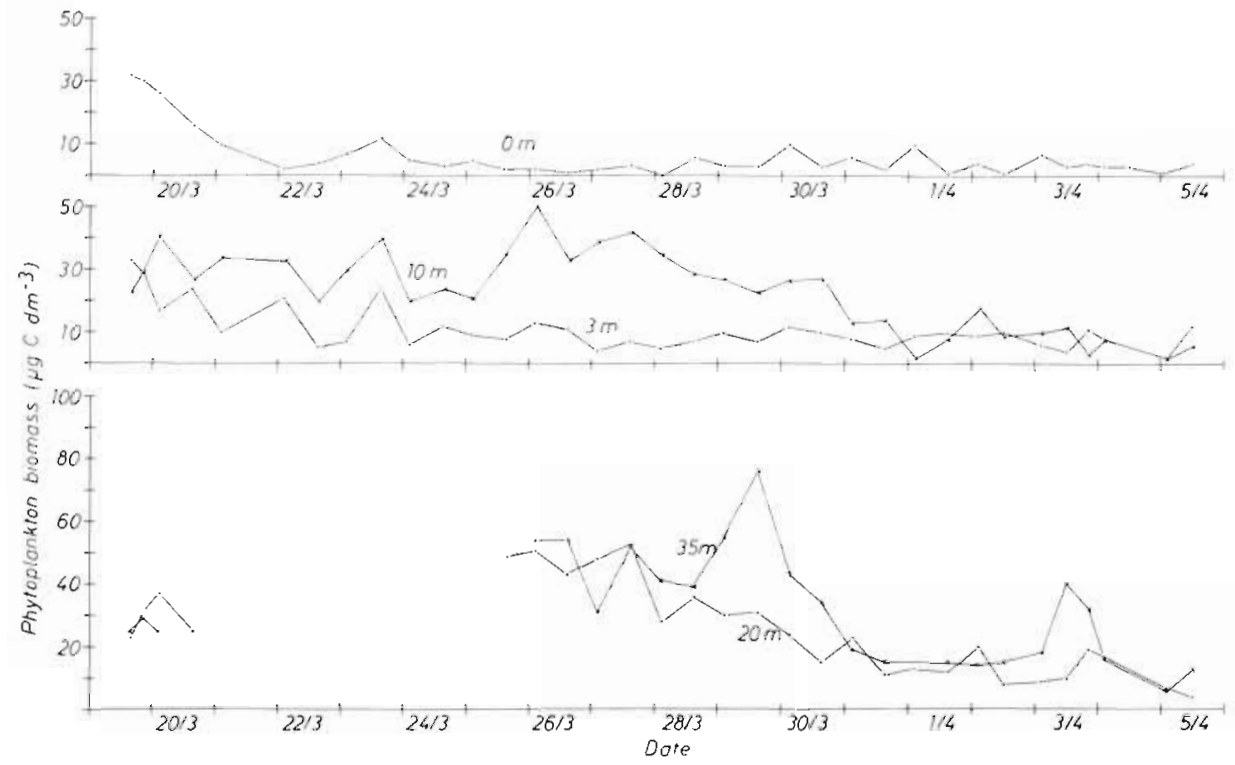

tribution was the same inside and outside of Bag BB. On March 20 the phytoplankton left the upper water layer and concentrated below $3 \mathrm{~m}$. From March 21 to 25, no sampling could be carried out below $10 \mathrm{~m}$ because Bag BB floated horizontally at a depth of about $15 \mathrm{~m}$, due to an influx of water into the fjord with higher salinity than that in the enclosure. On March 25 light Skagerrak water flowed into the fjord again. Thus, the measurements could be continued at all depths.

In the upper meters of the water column, phytoplankton concentrations were low. Maximum values occurred at $35 \mathrm{~m}$ with more than 200,000 cells $\mathrm{dm}^{-3}$ of Thalassiosira nordenskioeldii. Until the end of March phytoplankton decreased at all depths (Fig. 11). Especially $T$. nordenskioeldii decreased from mean concentrations of 150,000 cells $\mathrm{dm}^{-3}$ to about 8,000 cells $\mathrm{dm}^{-3}$. Other main species were Chaetoceros debilis, Rhizosolenia alata and Thalassionema nitzschioides, but they only occurred in low cell numbers.

At a given depth the distribution of nutrients revealed differences.. Nitrate (Fig. 12a) showed concentration changes at the surface with a maximum of $2.2 \mu \mathrm{g}$ at $\mathrm{N} \mathrm{dm}^{-3}$ around March 26. This peak may have been caused by snow falling into the enclosure (Kuiper, pers. comm.). Thereafter, the concentrations were about $0.9 \mu \mathrm{g}$ at $\mathrm{N} \mathrm{dm}{ }^{-3}$. At 3 and $10 \mathrm{~m}$ the initial values were different. Until March 26, also at these depths, concentrations of about $0.9 \mu \mathrm{g}$ at $\mathrm{N} \mathrm{dm}^{-3}$ were observed as well as at 20 and $35 \mathrm{~m}$ depth, where measurements were continued on March 25. The low fluctuations of nitrate are documented by variations of mean values: $13.4 \%$ at $3 \mathrm{~m} ; 7.5 \%$ at $10 \mathrm{~m} ; 7 \%$ at $20 \mathrm{~m}$; and $8.7 \%$ at $35 \mathrm{~m}$.

The different initial concentrations of silicate (Fig. 12b) were equalized at all depths on March 26. In contrast to nitrate, silicate became depleted at all depths by April 2. Upon silicate depletion, the phytoplankton decreased to minimum concentrations.

In contrast to nitrate and silicate, phosphate concentrations (Fig. 12c) increased slightly. In spite of the fact that the concentrations were near the limit of detection, a significant increase in mean phosphate concentration, from 0.02 to $0.1 \mu \mathrm{g}$ at $\mathrm{P} \mathrm{dm}{ }^{-3}$, could be established. On March 27 an uniform increase started at 20 and $35 \mathrm{~m}$. At 3 and $10 \mathrm{~m}$, the concentrations remained rather constant until April 1; thereafter they also increased. Ammonia concentrations showed a slight increase beginning on March 30. Up to this date the concentrations were essentially constant. On March 30 , mean values were about $1.46 \mu \mathrm{g}$ at $\mathrm{N} \mathrm{dm}^{-3}$, they then increased to more than $2.2 \mu \mathrm{g}$ at $\mathrm{N} \mathrm{dm}^{-3}$ (Kattner et al., 1982).

For Bag BB only a few zooplankton data are available. Numbers of organisms from profiles of the last $2 \mathrm{~d}$ show that the zooplankton biomass must have increased strongly during the experiment. Taking a zooplankton biomass of $3 \mu \mathrm{g} \mathrm{C} \mathrm{dm}{ }^{-3}$ in the fjord as being representative of the initial zooplankton in this enclosure, it becomes possible to calculate the increase in zooplankters: at the end of the experiment a value of more than $20 \mu \mathrm{g} \mathrm{C} \mathrm{dm}{ }^{-3}$ was determined; it was particularly due to the development of copepoditestages I to III of Calanus finmarchicus.

\section{Period 3: March 19 to April 5}

Fjord

On March 19, with a new water exchange, nutrientrich and haline water came into the fjord again and 

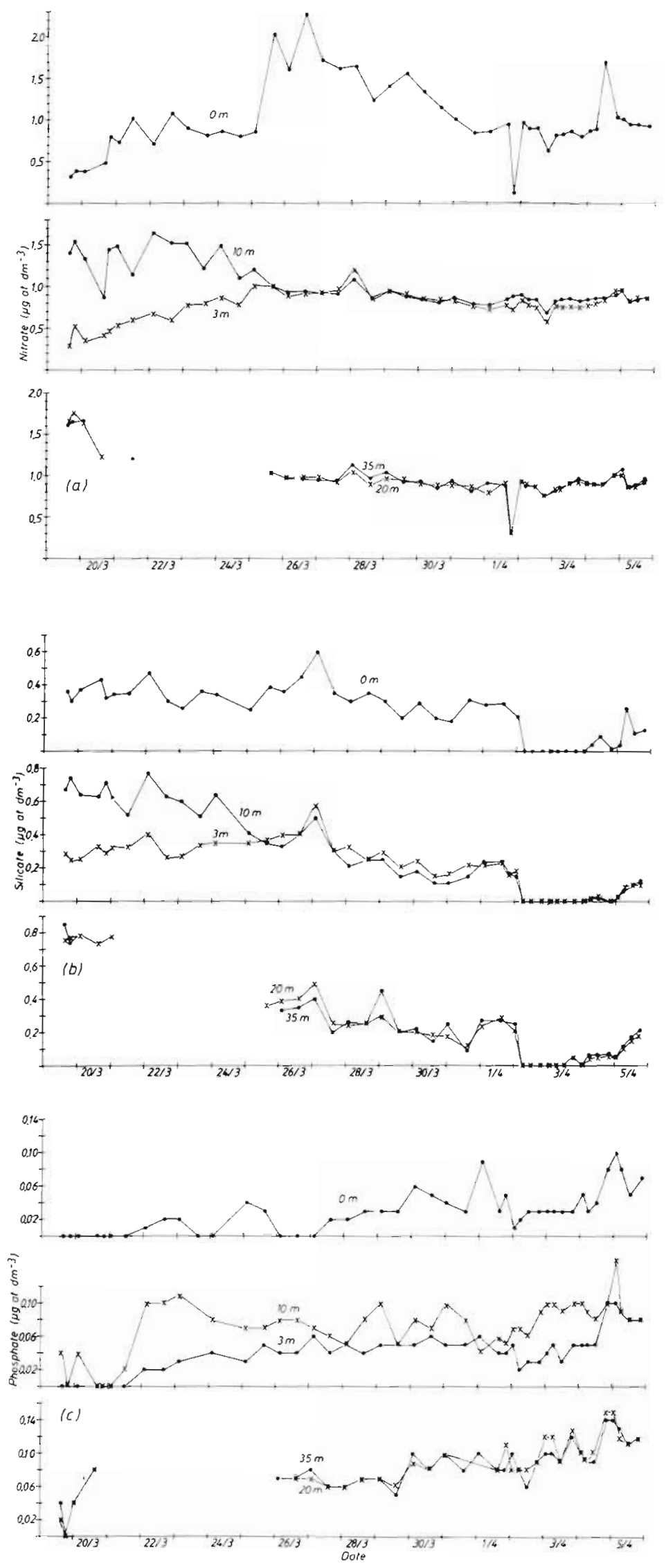

prevailed below a depth of $10 \mathrm{~m}$ on March 24/25. Maximum concentrations were: nitrate, $10 \mu \mathrm{g}$ at $\mathrm{N}$ $\mathrm{dm}^{-3}$; silicate, $6 \mu \mathrm{g}$ at $\mathrm{Si} \mathrm{dm}^{-3}$; phosphate, $0.7 \mu \mathrm{g}$ at $\mathrm{P}$ $\mathrm{dm}^{-3}$. Chlorophyll and phytoplankton concentrations were low. On March 25/26, the haline water was replaced by nutrient-poor Skagerrak water. In this water body the nutrients were not totally exhausted and chlorophyll and phytoplankton biomass showed higher concentrations (Fig. 2b) without reaching the concentrations of Period 2. A slight decrease in nutrient concentrations in this period was observed (Fig. 2a). Compared to Period 2, the species composition of phytoplankton had not changed.

The dominant species was again Thalassiosira nordenskioeldii but towards the end of Period 3 it nearly disappeared. There was no nutrient depletion in the fjord. Especially silicate did not decline below $1 \mu \mathrm{g}$ at Si $\mathrm{dm}^{-3}$, and nitrate and phosphate not below $2 \mu \mathrm{g}$ at $\mathrm{N}$ $\mathrm{dm}^{-3}$ and $0.1 \mu \mathrm{g}$ at $\mathrm{P} \mathrm{dm} \mathrm{dm}^{-3}$.

Parallel to the decrease in the phytoplankton standing stock, changes in composition occurred. The larger phytoplankters, especially Coscinodiscus sp. and Peridinium depressum, attained higher numbers, up to 50 cells $\mathrm{dm}^{-3}$ (Fig. 13). Due to their size $-196 \mu \mathrm{m} \varnothing$ for Coscinodiscus sp. and $128 \times 190 \mu \mathrm{m}$ for $P$. depressum, - they accounted for about $50 \%$ of the low phytoplankton biomass during the last days of the experiment (Fig. 2b).

The zooplankton biomass (Fig. 2c) reached maximum values (up to $10 \mu \mathrm{g} \mathrm{C} \mathrm{dm}^{-3}$ ) due to increases in copepodite-stages of Calanus finmarchicus. Its max. imum followed the maximum of phytoplankton growth. Nauplii numbers were in the same range as in Period 2 and decreased with increasing numbers of copepodites.

\section{Bag CC}

Bag CC was filled on March 21, when upwelling of nutrient-rich water occurred in the fjord. Stratification in the enclosure was similar to that in the fjord (Fig. 14). The pycnocline was between 10 and $20 \mathrm{~m}$ with a difference in salinity of $\mathrm{S}=3$. The pycnocline remained stable during the experiment. Phytoplankton species composition in the upper layer was the same as during Period 2.

In the upper layer, the homogeneous distribution of phytoplankton changed during the first days. Phytoplankton decreased at 0 and $3 \mathrm{~m}$ and increased at $10 \mathrm{~m}$ (Fig. 15). At $10 \mathrm{~m}$, maximum concentrations of up to $100 \mu \mathrm{g} \mathrm{C} \mathrm{dm}{ }^{-3}$ were reached on March 26 to 28.

Fig. 12. Nutrient concentrations in Bag BB at different depths. (a) Nitrate; (b) silicate; (c) phosphate 
Fig. 13. Coscinodiscus sp. (o) and Peridinium depressum (•) development in the fjord

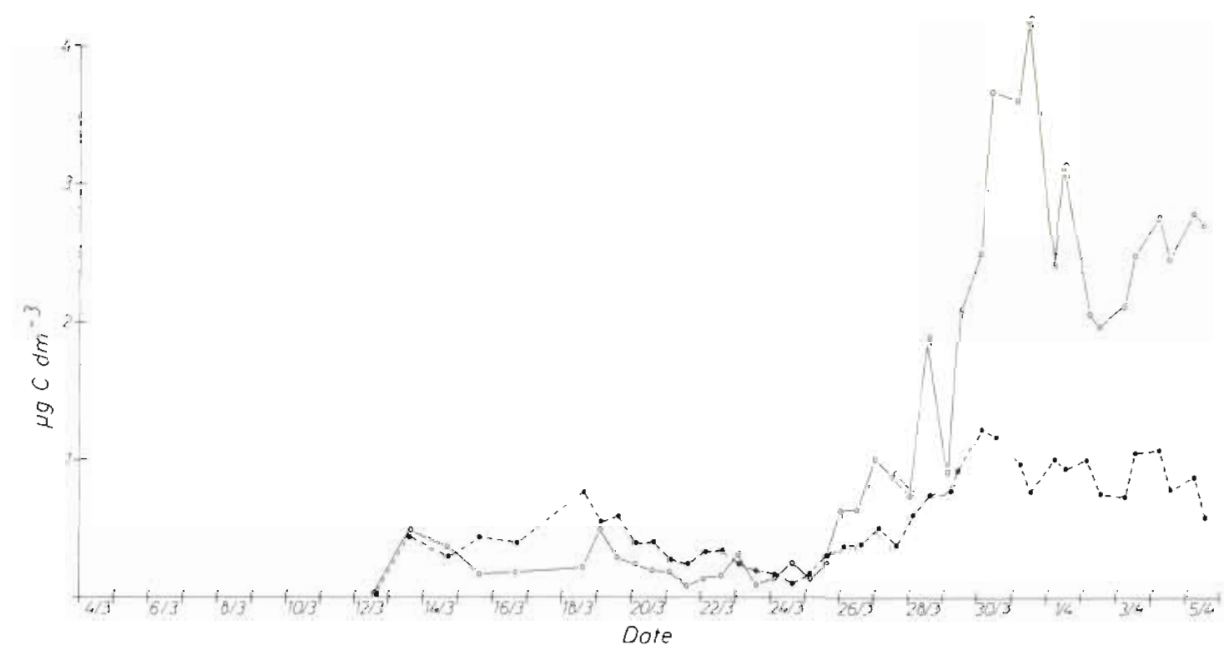

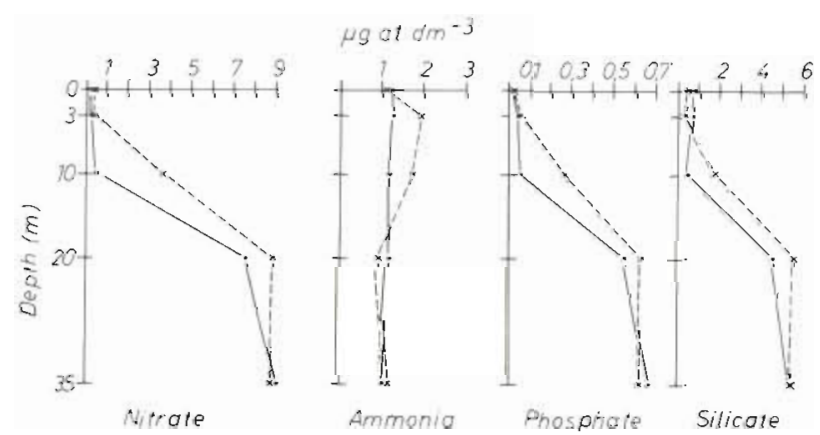

Fig. 14. Profiles of nutrient concentrations during filling of Bag CC at 18.30 h on March 21. . fjord; $x$ enclosed in Bag CC

While at different sampling depths nutrients showed different concentration changes, their concentrations averaged over the various depths remained rather constant. At 0 and $3 \mathrm{~m}$, nitrate (Fig. 16a) and the other nutrients increased progressively. At $10 \mathrm{~m}$, nitrate was about $3.5 \mu \mathrm{g}$ at $\mathrm{N} \mathrm{dm}^{-3}$, decreasing from March 26 to 28 during maximum occurrence of phytoplankton, and then increasing by about $1 \mu \mathrm{g}$ at $\mathrm{N} \mathrm{dm}^{-3}$. At $20 \mathrm{~m}$, a decrease of about $1.5 \mu \mathrm{g}$ at $\mathrm{N} \mathrm{dm}{ }^{-3}$ was observed during the experiment. The mean nitrate concentration, averaged over all depths, was nearly constant: $6.48 \pm 2.6 \% \mu \mathrm{g}$ at $\mathrm{N} \mathrm{dm}^{-3}$.

The distributions of silicate (Fig. 16b) and phosphate revealed similar patterns. In contrast to nitrate, a slight decrease of these nutrients, averaged over all depths, occurred during the experiment. Variation of mean concentrations was $7.7 \%$ for silicate, and $7.1 \%$ for phosphate. At $35 \mathrm{~m}$ concentrations were for nitrate, $9.07 \pm 3.1 \% \mu \mathrm{g}$ at $\mathrm{N} \mathrm{dm}^{-3}$; for silicate, $4.84 \pm 6.8 \% \mu \mathrm{g}$ at Si $\mathrm{dm}^{-3}$; and for phosphate, $0.61 \pm 4.9 \% \mu \mathrm{g}$ at $\mathrm{P}$ $\mathrm{dm}^{-3}$.

Increases in larger phytoplankters, observed in the fjord, could not be recorded in Bag CC. A short increase of Peridinium depressum occurred only at
$10 \mathrm{~m}$, following the maximum of smaller phytoplankton species.

Fig. 17 shows the decrease of Thalassiosira nordenskioeldii at $3 \mathrm{~m}$. While the fluctuations in the fjord as well as in Bags $\mathrm{BB}$ and $\mathrm{CC}$ are not explainable, decreases in these algae were evident. Maximum cell numbers were found in Bag $\mathrm{CC}$. Cell numbers decreased in the fjord and in Bag CC in spite of slightly increasing nutrient concentrations (Fig. 16). At $10 \mathrm{~m}$, cell numbers of $T$. nordenskioeldii were generally higher than at $3 \mathrm{~m}$. In Bag $\mathrm{CC}$ a short growth period could be observed due to a higher nutrient concentration near the pycnocline. But after $1 \mathrm{wk} T$. nordenskioeldii disappeared completely in spite of sufficient nutrients.

Averaged over all depths, the zooplankton numbers in the enclosure increased. The first copepodite-stages of Calanus finmarchicus appeared especially below $3 \mathrm{~m}$ (Fig. 18). Other zooplankters showed essentially no increasing numbers. Increasing numbers of $C$. finmarchicus followed the maximum of phytoplankton, and at the end of March reached more than $60 \%$ of the phytoplankton carbon with maximum values of more than $100 \%$.

\section{DISCUSSION}

In the fjord the water was exchanged several times. Comparison of nutrient data with salinity, temperature and current-meter measurements (Brockmann et al., 1981) revealed that the main changes were due to hydrodynamic influences. The results show that developments in enclosures and in the surrounding water are comparable. 

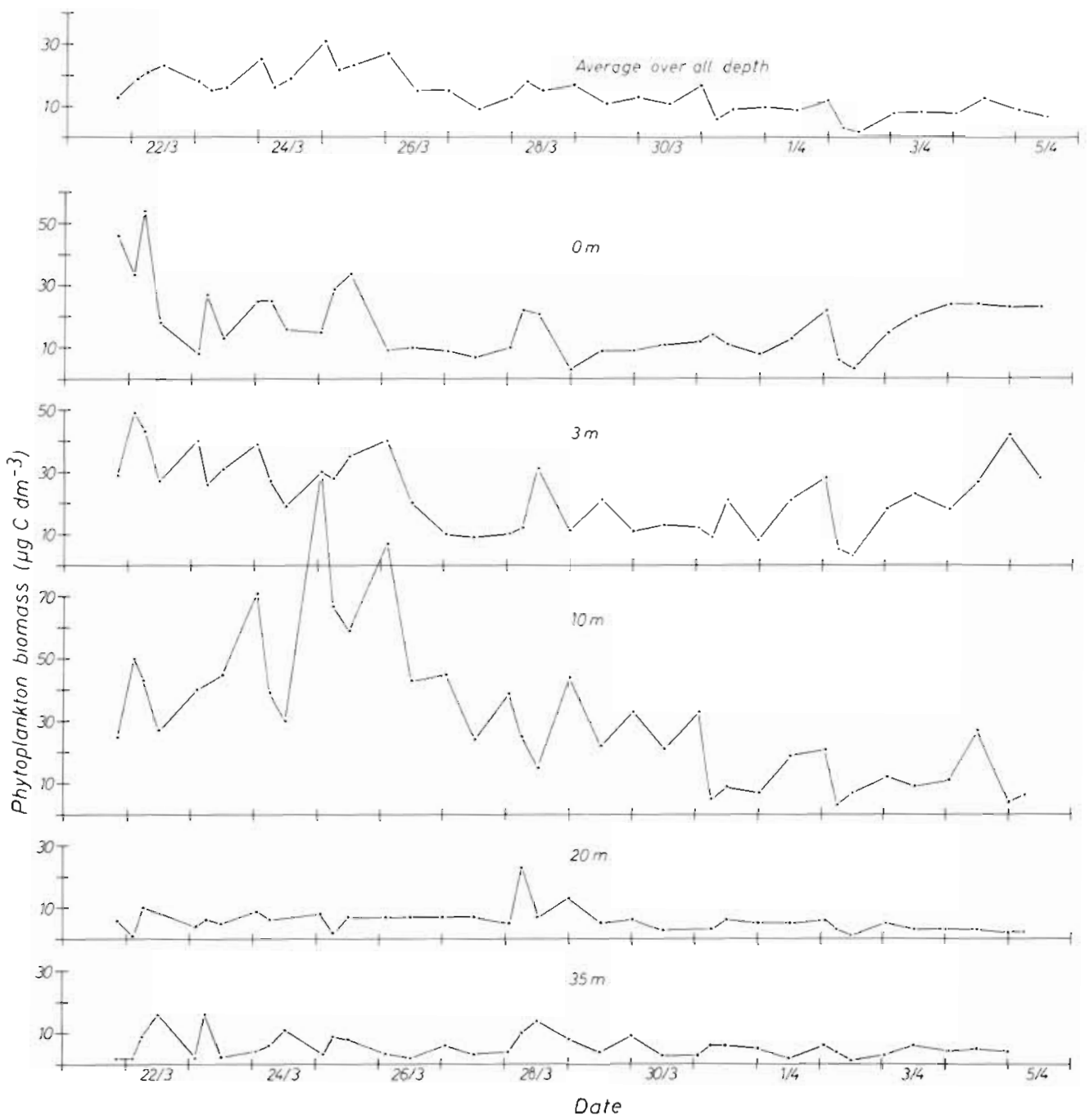

Fig. 15. Concentration of phytoplankton biomass in Bag CC at different depths

Period 1

At the beginning of the experiment the nutrient-rich and haline water in the fjord could be characterized as Atlantic water. The slight stratification of nutrients (as exemplified in Fig. 5), already present when the enclosures were filled, had been caused by a previous phytoplankton bloom dominated by Skeletonema costatum. The phytoplankton biomass was low, because $S$. costatum cells are very small. Thalassiosira nordenskioeldii - which later became the main species - was already present in the fjord in low numbers.

Under good growth conditions, i.e. temperatures above $5^{\circ} \mathrm{C}$ and high light intensities (Jitts et al., 1964; Guillard and Kilham, 1977), the spring bloom is often initiated by Skeletonema costatum. Paasche and Ostergren (1980) described a large $S$. costatum bloom in the Oslo Fjord in February/March in 1978. This bloom occurred in spite of very low temperatures (average $2.2^{\circ} \mathrm{C}$ ) and was favoured by improving light conditions. Hitchcock and Smayda (1977) also reported a $S$. costatum bloom at temperatures between 1 and $2{ }^{\circ} \mathrm{C}$. This indicates that temperature may have little direct effect on bloom inception. It can thus be inferred that the $S$. costatum bloom during this period was also dependent on light intensities, since measurements at a nearby station in Kjevik showed light intensities which decreased at the end of February and at the beginning of March until March 8 (Fig. 3). The $S$. costatum bloom must have been in a late growth phase when the experiment started. Assuming that nutrient stratification was caused mainly by $S$. costatum, calculations of nutrient consumption indicate that previously there had been a bloom of several millions of cells per liter of $S$. costatum. This was supported by some samples with several millions of $S$. costatum per 
Fig. 16. Nutrient concentrations in Bag CC at different depths
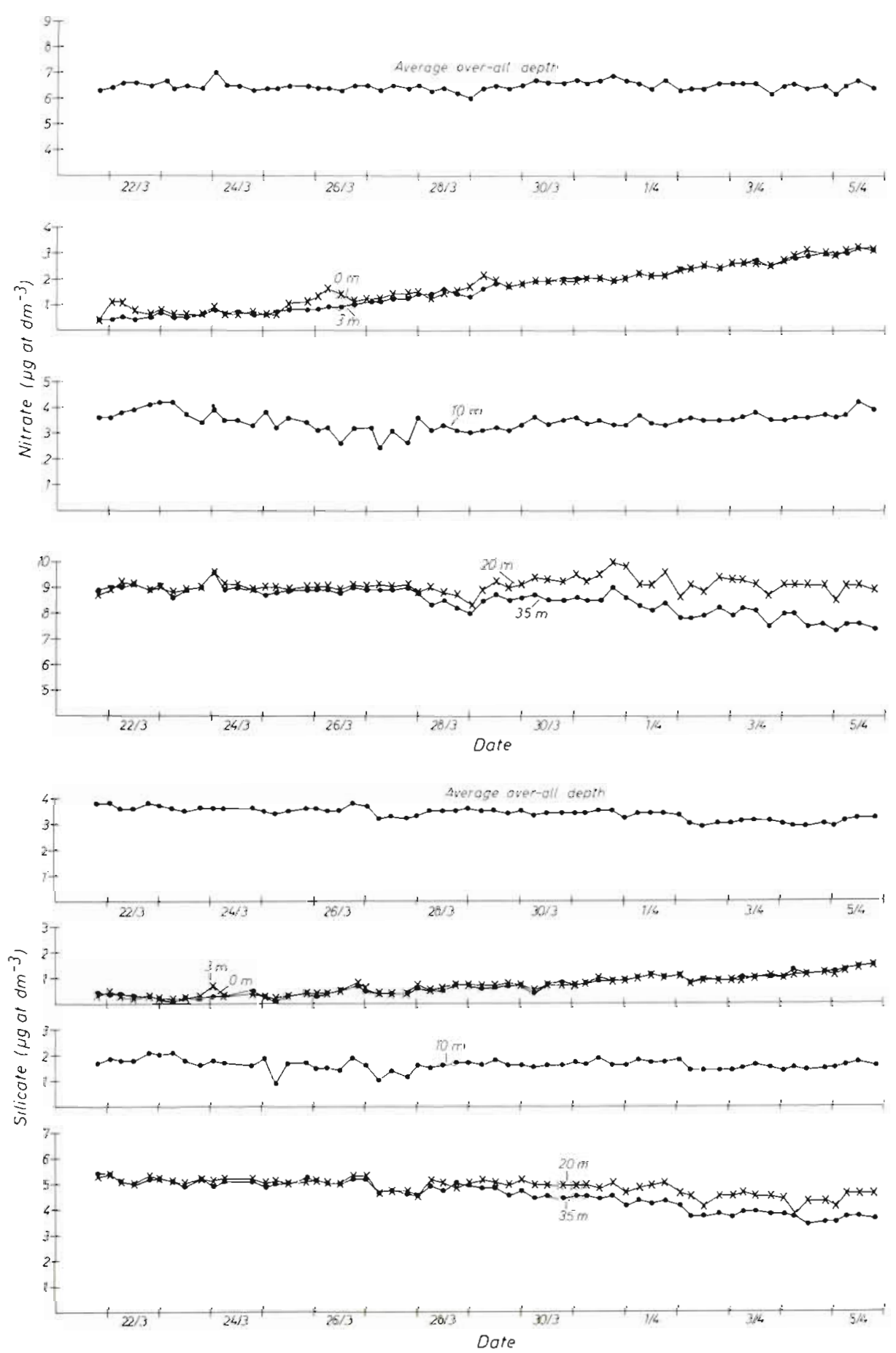

liter on March 5. Calculations of the nutrient consumption could be performed, based on results from a parallel enclosure experiment with a monoculture of $S$. costatum under similar conditions (Eberlein et al., 1983).

In contrast to the fjord, in the enclosures one doubling of cells of Skeletonema costatum with a division rate of about $0.6 \mathrm{~d}^{-1}$ was observed, possibly caused by reduction of turbulence in the enclosed water. However, by March $8 \mathrm{~S}$. costatum disappeared in both enclosures as well as in the fjord (Fig. 8). Since nutrient concentration, temperature and water masses in the fjord did not change, and zooplankton pressure was absent, it seems probable that only low light intensity may have caused the disappearance of $S$. costatum. The presence of some adult females of Calanus finmar- 


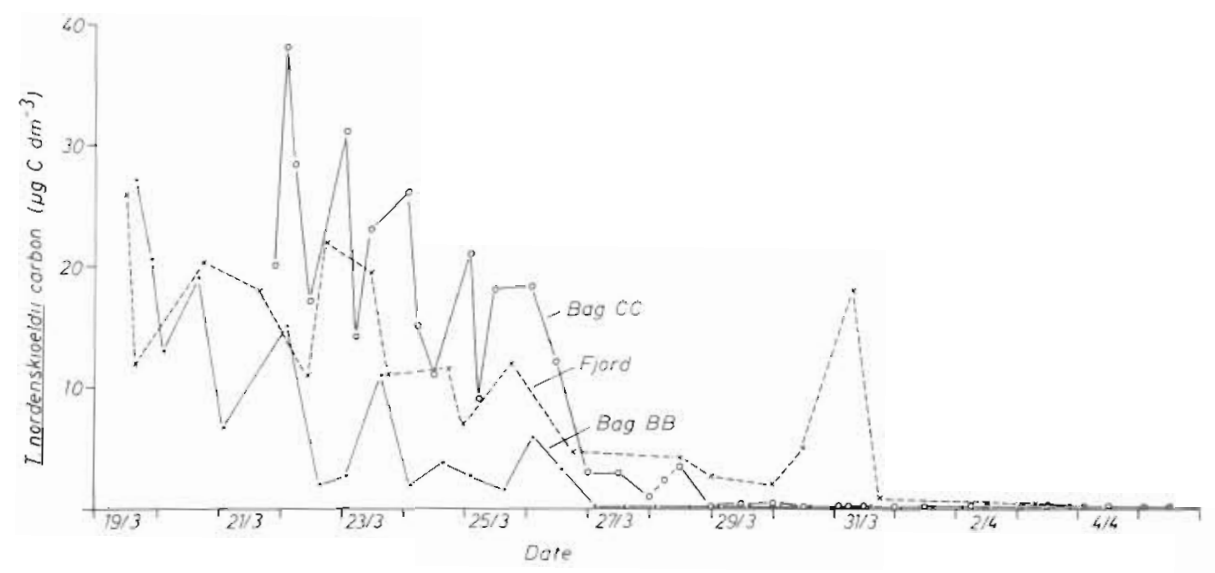

Fig. 17. Thalassiosira nordenskioeldii. Development at $3 \mathrm{~m}$ depth. $\times$ fjord; $\circ \mathrm{Bag} \mathrm{CC}_{i} \cdot \mathrm{Bag} \mathrm{BB}$
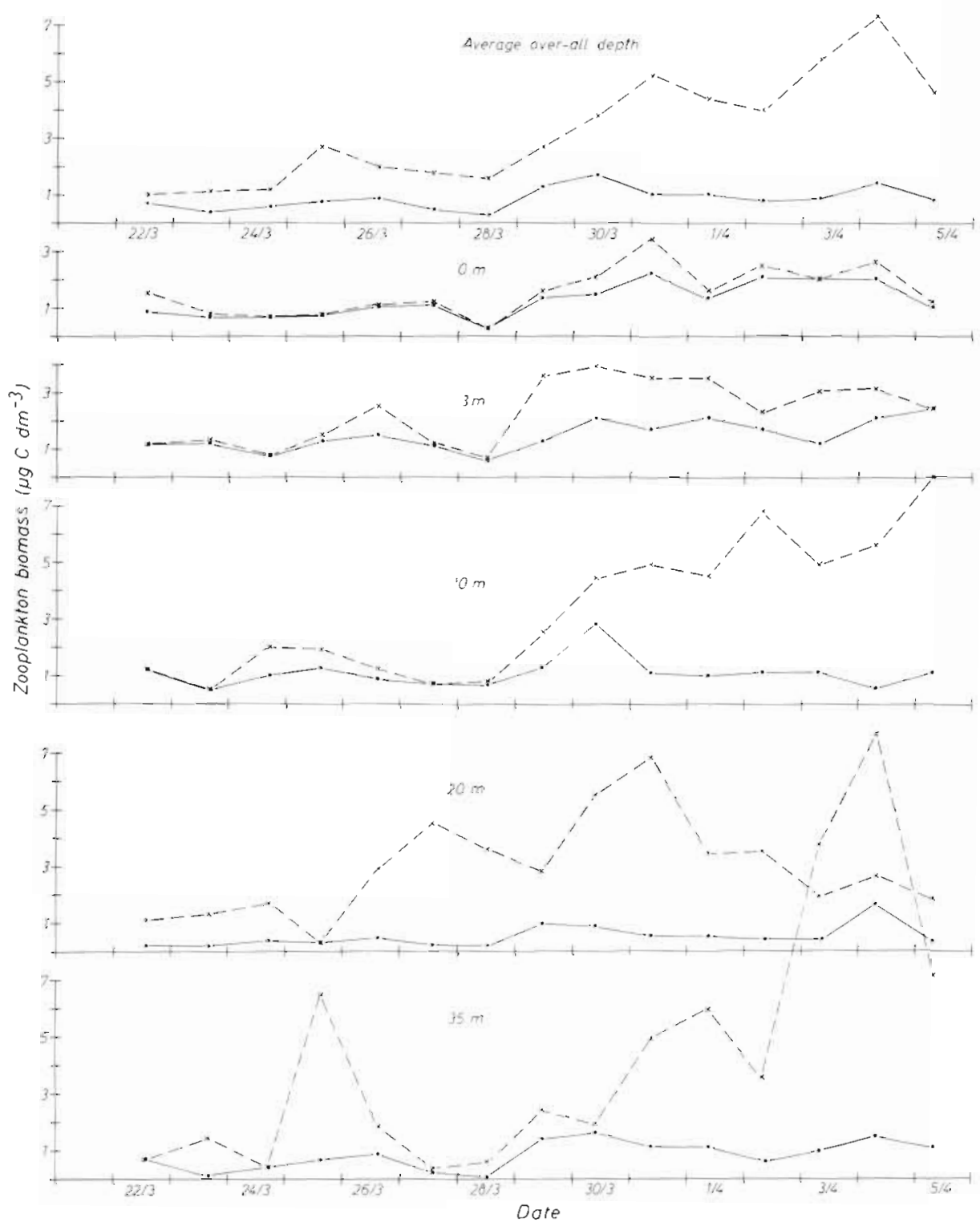

Fig. 18. Concentration of zooplankton biomass in Bag $\mathrm{CC}$ at different depths. $x$ total biomass; - biomass without copepods and copepodite-stages 
chicus in hibernation stages was characteristic for the water body during the first period (Krause and Kattner, 1983).

\section{Period 2}

Unfortunately, the 2 enclosures had to be abandoned on March 14 due to water exchange in the fjord resulting from an outflow of Skagerrak water (Aure and Saetre, 1981; Svendsen, 1981); however, in a control bag used for oil-pollution experiments, further phytoplankton and nutrient developments could be observed until the end of POSER (Brockmann et al., 1982; Dahl et al., 1983). In this enclosure a progressive phytoplankton development started on March 15 coupled with nutrient depletion. Skeletonema costatum disappeared simultaneously in the fjord and in Bags $U$ and $V$, but occurred with small cell numbers over the entire period. The $S$. costatum population was replaced by a bloom of Thalassiosira nordenskioeldii in particular, and by Chaetoceros debilis.

The development in this enclosure was remarkably similar to that of the fjord. Both developments were caused by different events. In the fjord the species composition changed as a result of water exchange, and in the enclosure a typical spring bloom succession (Guillard and Kilham, 1977) occurred, resulting in a similar phytoplankton population in both systems. This supports the transferability of enclosure-experiment results to natural systems.

In the fjord, the change of the dominant phytoplankters, Skeletonema costatum and Thalassiosira nordenskioeldii, was a sequence (Gran and Braarud, 1935, reviewed by Smayda, 1980) due to the change from Atlantic to Skagerrak water, and in the enclosures a succession could be observed. The first stages of the succession in the enclosures and of the succession and sequence in the fjord seemed to be mainly dependent on physical factors such as light and temperature. The inflow of cold (about $2{ }^{\circ} \mathrm{C}$ ) Skagerrak water into the fjord resulted in lower temperatures in the control bag used for oil-pollution experiments within $2 \mathrm{~d}$. This favoured the growth of the cold-water species $T$. nordenskioeldii, which increased after several days until nutrients were exhausted. Thus, the cold water in the fjord seemed to have induced the succession in the enclosure of the same phytoplankton species as in the fjord. Therefore it may be questioned whether a real succession occurred in the enclosure, since the phytoplankton would have developed differently if the temperature had not been altered by the influence of the new surrounding water body.

Thalassiosira nordenskioeldii is a cold-water species able to grow at low temperatures and light intensities
(Jitts et al, 1964; Durbin, 1974). As the Skagerrak water was cold (about $2^{\circ} \mathrm{C}$ ) and light intensities were low, it seems that growth conditions were better for $T$. nordenskioeldii than for Skeletonema costatum. This might have caused the population change discussed above. T. nordenskioeldii probably has higher growth rates than $S$. costatum, if both temperature and light intensity are low; $S$. costatum too can grow at very low temperatures (Paasche and Østergren, 1980; Eberlein et al., 1983).

In the Skagerrak water entering the fjord the nutrients were already exhausted and the exponential phytoplankton growth had occurred previously. This bloom seems primarily to have been limited by the depletion of nutrients and not by zooplankton grazing, because the zooplankton biomass was only $5 \%$ of the phytoplankton biomass. This limitation is also concluded for the decay of the spring phytoplankton bloom in the open sea (Fransz and van Arkel, 1980); Fransz and Gieskes, 1982; Radach et al., 1983).

A further characterization of the Skagerrak water was the increase of zooplankton biomass. In contrast to the first period a new generation of copepods had developed, resulting in an increase of nauplii (Krause and Kattner, 1983). Marshall and Orr (1952) suggested that egg-laying of Calanus is dependent on food, that is, it starts at the onset of the diatom spring bloom. The time lag between the appearance of copepod eggs and nauplii of about $10 \mathrm{~d}$ (Krause and Radach, 1980) corroborates the assumption that the phytoplankton bloom was in its late stages (Krause and Kattner, 1983).

Period 3

Further direct comparisons of plankton development were prevented by a new inflow of water masses below $10 \mathrm{~m}$ depth. However, in the upper layer, due to the similar nutrient concentrations, a comparison of the distribution of phytoplankton in the fjord with Bag BB and Bag CC seems possible. Thalassiosira nordenskioeldii - the dominant species - decreased (Fig. 17) in spite of low but sufficient and increasing nutrient concentrations.

In Bag BB the phytoplankton stock decreased earlier due to exhaustion of silicate in combination with grazing of zooplankton, which strongly increased. The results for Bag BB show that very low nutrient concentrations are sufficient to maintain the small phytoplankton stock. The collapse of the standing stock did not occur until silicate was totally exhausted and zooplankton pressure was relatively high. The limited data on zooplankton distribution permit a few remarks. The decrease of nauplii was related to the development of copepodite stages, the numbers of which 
increased greatly. A new generation of copepodites, appearing about 10 to $12 \mathrm{~d}$ after the nauplii, had developed.

When filling this enclosure, phosphate concentrations had been almost at the detection limit. During this period, phosphate increased, indicating higher remineralization rates than in the phytoplankton stock. The greatest increase of phosphate and ammonia and, finally, also nitrate was caused by the stagnation of phytoplankton at the end of the experiment. Thus, in Bag $\mathrm{BB}$ initial remineralization processes following the spring phytoplankton bloom could be investigated. Loss by sedimentation did not seem to be important, as shown by a reasonable balance of phosphorus compounds (Kattner et al., 1982).

In the fjord and Bag $\mathrm{CC}$, nutrient concentrations rose slightly caused by mixing with the nutrient-rich lower layer by diffusion and turbulence, and also in Bag CC by frequent sampling (Fig. 16). Since nutrient concentrations seem to be sufficient for further diatom growth, Thalassiosira nordenskioeldii disappeared in both systems. The first bloom of $T$. nordenskioeldii in the Skagerrak water had exhausted nearly all the nutrients. Thus, it seems that the subsequent slight increase in nutrients was insufficient to induce a second bloom of $T$. nordenskioeldii. Only at $10 \mathrm{~m}$ depth in Bag CC did a short growth period occur; it terminated on March 26, probably due to the sudden deterioration of growth conditions. In addition to low nutrient concentrations, the temperature decreased due to the inflow of colder water into the fjord and light intensities also decreased (Fig. 3). Thereafter, more damaged cells were found below $10 \mathrm{~m}$ (Jahnke et al., 1983). Early disappearance of the spring phytoplankton in spite of sufficient nutrient concentrations has been observed previously (e.g. Braarud, 1962, cited in Paasche, 1975; Pratt, 1965). Only the large phytoplankters, especially Coscinodiscus sp. (Fig. 13), increased in the fjord, probably due to selective grazing by zooplankton.

After decreases in phytoplankters, the zooplankton biomass, mainly consisting of copepodite-stages I to III of Calanus finmarchicus, greatly increased. Since only 1 sample was taken in the morning, diurnal migration could not be estimated. The young copepadite-stages do not migrate if the food supply is sufficient; they migrate only when the food is depleted (Krause and Trahms, 1982), as was the case during the final period beginning around March 30. Thereafter, increasing numbers of copepodite-stages were also found at $35 \mathrm{~m}$.

At the end of the experiment the zooplankton biomass had reached more than $50 \%$ of the phytoplankton biomass. About $80 \%$ of the zooplankton biomass consisted of copepodite stages I to III of Calanus finmarchicus (Krause and Kattner, 1983).
Younger copepodites feed more than older stages (Daro, 1980) in relation to their body weight. Under favourable conditions, the feeding capacity of Calanus may be enormous. Cushing and Vucetic (1963) suggested a daily food intake of about $390 \%$ of the body weight, and Gaudy (1974) of about 250 to $300 \%$. During a declining spring bloom in the North Sea, Gamble (1978) found a maximum daily intake of $50 \%$. If the phytoplankton concentration is low, Calanus seems to be able to utilize fecal pellets and particulate matter as food (Paffenhöfer and Strickland, 1970; Radach et al., 1983). Thus, it may be concluded that under the conditions which prevailed during POSER phytoplankton was diminished by zooplankton grazing, so that no further phytoplankton growth was possible, in spite of sufficient nutrients. The zooplankton thus had to use detrital material in addition to phytoplankton as food. This was especially the case in Bag CC, where only the number of copepodites increased (Krause and Kattner, 1983). In enclosures feeding is more limited than in the open water, where zooplankton may migrate to regions with better food conditions. These may also be improved by changing the water. This will sometimes cause differences between the plankton development in enclosed and in open systems, e.g. the growth of large-sized phytoplankters in the fjord in contrast to Bag CC. This difference seems to be a direct effect of the selective grazing of Calanus on smaller diatoms ( 5 to $40 \mu \mathrm{m}$ ) (Gamble, 1978; Huntley, 1981). On the other hand, Calanus is able to destroy algae at the rate of 3 to 6 times of its probable metabolic need (Cushing and Vucetic, 1963), especially if the food concentration is low (Bag CC). A succession from small to larger phytoplankters is commonly observed (e.g. review by Guillard and Kilham, 1977).

Acknowledgements. We are grateful for good cooperation of the POSER team during the experiment. For important technical assistance in the analysis of data we thank I. Büns, G. Kramm, R. Lucht, H. Wierhake and R. Kopp, and for careful sorting of zooplankton material, G. Carretero Alcobendas and J. Beil. Thanks are also due to B. Kronberg for discussions on the manuscript. The work was supported by 'Deutsche Forschungsgemeinschaft' 'hrough 'Sonderforschungsbereich 94 - Meeresforschung - Hamburg'.

\section{LITERATURE CITED}

Aure, J., Saetre, R. (1981). Wind effects on the Skagerrak outflow. In: Saetre, R., Mork, M. (ed.) The Norwegian coastal current, Vol. I. Universität of Bergen, p. 263-293

Brockmann, U. H., Dahl, E., Kuiper, J., Kattner, G. (1983). The concept of POSER (Plankton observation with simultaneous enclosures in Rosfjorden). Mar. Ecol. Prog. Ser. 14: 1-8

Brockmann, U. H., Eberlein, K., Junge, H. D., Trageser, H., Trahms, K. J. (1974). Einfache Folientanks zur Planktonuntersuchung in situ. Mar. Biol. 24: 163-166 
Brockmann, U. H., Hentzschel, G. (1983). Samplers for enclosed stratified water columns. Mar. Ecol. Prog. Ser. 14: $107-109$

Brockmann, U. H., Kattner, G., Dahl, E. (1982). Plankton spring development in a south Norwegian fjord. In: Grice, G. D., Reeve, M. R. (ed.) Marine mesocosms. Springer Verlag, New York, p. 195-204

Brockmann, U. H., Koltermann, K. P., Dahl, E., Dahle, A., Eberlein, K., Gaertner, A., Gassmann, G., Hammer, K. D., Jahnke, J., Kattner, G., Krause, M., Kuiper,-J., Laake, M., Nagel, K. (1981). Water exchange in Rosfjorden during spring ' 79 , a detailed account of physical, chemical and biological variations. In: Saetre, R., Mork, M. (ed.) The Norwegian coastal current, Vol. I. University of Bergen, p. $93-130$

Cushing, D. H., Vucetic, T. (1963). Studies on a Calanus patch. III. The quantity of food eaten by Calanus finmarchicus. J. mar. biol. Ass. U. K. 43: 349-371

Dahl, E., Laake, M., Tjessem, K., Eberlein, K., Bøhle, B. (1983). Effects of Ekofisk crude oil on an enclosed planktonic ecosystem. Mar. Ecol. Prog. Ser. 14: 81-91

Daro, M. H. (1980). Field study of the diel feeding of a population of Calanus finmarchicus at the end of a phytoplankton bloom. "Meteor" Forschungsergeb. A 22: 123-132

Durbin, E. G. (1974). Studies on the autecology of the marine diatom Thalassiosira nordenskioeldii Cleve. I. The influence of daylength, light intensity, and temperature on growth. J. Phycol. 10: 220-225

Eberlein, K., Brockmann, U. H., Hammer, K. D., Kattner, G., Laake, M. (1983). Total dissolved carbohydrates in an enclosure experiment with unialgal Skeletonema costatum culture. Mar. Ecol. Prog. Ser. 14: 45-58

Fransz, H. G., van Arkel, W. G. (1980). Zooplankton activity during and after the phytoplankton spring bloom at the central station in the FLEX box, northern North Sea, with special reference to the calanoid copepod Calanus finmarchicus (Gunn.). "Meteor" Forschungsergeb. A 22: 113-121

Fransz, H. G. Gieskes, W. W C. (1982). The unbalance of phytoplankton production and copepod production in the North Sea. ICES Symposium on Biological Production of Continental Shelves, Kiel, F. R. G., 2-5 March 1982, No. 22, p. $1-18$

Gamble, J. C. (1978). Copepod grazing during a declining spring phytoplankton bloom in the northern North Sea. Mar. Biol. 49: 303-315

Gaudy, R. (1974). Feeding four species of pelagic copepods under experimental conditions. Mar. Biol. 25: 125-141

Guillard, R. R. L., Kilham, P. (1977). The ecology of marine planktonic diatoms. In: Wemer, D. (ed.) The biology of diatoms. Blackwell Scientific Publications, Oxford, p. $372-469$

Hitchcock, G. L., Smayda, T. J. (1977). The importance of light in the initiation of the 1972-1973 winter - spring diatom bloom in Narragansett Bay. Limnol. Oceanogr. 22 (1): 126-131

Huntley, M. (1981). Nonselective, nonsaturated feeding by three calanoid copepod species in the Labrador Sea. Limnol. Oceangr. 26: 831-842

Jahnke, J., Brockmann, U. H., Aletsee, L., Hammer, K. D.
(1983). Phytoplankton activity in enclosed and free marine ecosystems in a southern Norwegian fjord during spring 1979. Mar. Ecol. Prog. Ser. 14: 19-28

Jitts, H. R., McAllister, C. D., Stephens, K., Strickland, J. D. H (1964). The cell division rates of some marine phytoplankters as a function of light and temperature. J. Fish. Res. Bd Can. 21: 139-157

Kattner, G., Brockmann, U. H., Eberlein, K., Hammer, K. D. Jahnke, J. (1982). Enclosed planktonic ecosystems during different stages of a spring bloom in south Norway. Neth. J. Sea Res. 16: 353-361

Krause, M., Kattner, G. (1983). Zooplankton composition and development in the Rosfjord and in different enclosures during POSER '79. In prep.

Krause, M., Radach, G. (1980). On the succession of developmental stages of herbivorous zooplankton in the northern North Sea during FLEX '76. I. First statements about the main groups of the zooplankton community. "Meteor" Forschungsergeb. A 22: 133-149

Krause, M., Trahms, J. (1982). Vertical distribution of copepod stages and other zooplankton during spring bloom in the Fladen Ground area of the North Sea. Neth. J. Sea Res. 16: $217-230$

Lorenzen, C. J. (1967). Determination of chlorophyll and pheopigments. Spectrophotometric equations. Limnol. Oceanogr. 12: 343-346

Marshall, S. M., Orr, A. P. (1952). On the biology of Calanus finmarchicus. VII. Factors affecting egg production. J. mar. biol. Ass. U. K. 30: 527-547

Paasche, E. (1975). Growth of the plankton diatom Thalassiosira nordenskioeldii Cleve at low silicate concentrations. J. exp. mar. Biol. Ecol. 18: 173-183

Paasche, E., Østergren, I. (1980). The annual cycle of plankton diatom growth and silicate production in the inner Oslofjord. Limnol. Oceanogr 25 (3): 481-494

Paffenhöfer, G.-A., Strickland, J. D. H. (1970). A note on the feeding of Calanus helgolandicus on detritus. Mar. Biol. 5: 97-99

Pratt, D. M. (1965). The winter-spring diatom flowering in Narragansett Bay. Limnol. Oceanogr. 10: 173-184

Radach, G., Berg, J., Heinemann, B., Krause, M. (1983). On the relation of primary production and herbivorous zooplankton grazing in the northern North Sea during FLEX 76. In: Fasham, M. (ed.) Flows of energy and materials in marine ecosystems: theory and praxis. Plenum Press, New York (in press)

Smayda, T J. (1980). Phytoplankton species succession. In: Morris, I. (ed.) The physiological ecology of phytoplankton. Blackwell Scientific Publications, Oxford, p. 493-570

Smetacek, V. (1975). Die Sukzession des Phytoplanktons in der westlichen Kieler Bucht. Dissertation, Universität Kiel

Svendsen, H. (1981). Wind-induced variations of circulation and water level in coupled fjord-coast systems. In: Saetre, R., Mork, M. (ed.) The Norwegian coastal current, Vol. I. University of Bergen, p. 229-262

Williams, R., Lindley, J. A. (1980). Plankton of the Fladen Ground during FLEX 76. III. Vertical distribution, population dynamics and production of Calanus finmarchicus (Crustacea: Copepoda). Mar. Biol. 60: 47-56 